\title{
Role of NELF-B in supporting epithelial-mesenchymal transition and cell proliferation during hepatocellular carcinoma progression
}

\author{
MENNATALLAH HANI GHOURABA $^{1 *}$, RAZAN JAMIL MASAD $^{1 *}$, ERIC ZADOK MPINGIRIKA ${ }^{1}$, \\ OMNIA MAHMOUD ABDELRAHEEM ${ }^{1}$, RACHED ZEGHLACHE ${ }^{2}$, AYA M ALSERW $^{2}$ and ASMA AMLEH ${ }^{1,2}$ \\ Departments of ${ }^{1}$ Biotechnology and ${ }^{2}$ Biology, School of Sciences and Engineering, \\ The American University in Cairo, New Cairo 11835, Egypt
}

Received January 15, 2021; Accepted June 18, 2021

DOI: $10.3892 / \mathrm{ol} .2021 .13022$

\begin{abstract}
Negative elongation factor-B (NELF-B), also known as cofactor of BRCA1 (COBRA1), is one of the four subunits of the NELF complex. It interacts with BRCA1, in addition to other transcription complexes in various tissues. The NELF complex represses the transcription of several genes by stalling RNA polymerase II during the early phase of transcription elongation. The role of NELF-B in liver cancer and hepatocellular carcinoma (HCC), the most prevalent type of liver cancer, remains to be elucidated. It has been previously demonstrated that silencing of NELF-B inhibits the proliferation and migration of HepG2 cells. The present study aimed to investigate the consequences of ectopic expression and silencing of NELF-B in liver cancer HepG2 and SNU449 cell lines. Functional assays were performed to examine the effects on gene and protein expression, viability, migration and invasion of cells. Overexpression of NELF-B did not alter the proliferation and migration of HepG2 cells, or the expression of tested genes, indicating that overexpression alone may not be sufficient for altering these features in HepG2 cells. By contrast, knockdown of NELF-B in SNU449 cells resulted in decreased cell proliferation, together with induction of apoptosis and decreased expression levels of Ki-67 and survivin, which are markers of proliferation and inhibition of apoptosis, respectively. Additionally, silencing of NELF-B resulted in a significant
\end{abstract}

Correspondence to: Dr Asma Amleh, Department of Biology, School of Sciences and Engineering, The American University in Cairo, AUC Avenue, P.O. Box 74, New Cairo 11835, Egypt

E-mail: aamleh@aucegypt.edu

*Contributed equally

Abbreviations: COBRA1, cofactor of BRCA1; EMT, epithelial-mesenchymal transition; $\mathrm{ER} \alpha$, estrogen receptor $\alpha$; FOXF2, forkhead box F2; HBV, hepatitis B virus; HCC, hepatocellular carcinoma; NELF, negative elongation factor; RT-qPCR, reverse transcription-quantitative PCR; TFF1/3, trefoil factor $1 / 3$

Key words: COBRA1, NELF, migration, invasion decrease in the hallmarks of epithelial-mesenchymal transition (EMT), including cell migration and invasion, and decreased the expression levels of EMT markers, such as N-cadherin, vimentin and $\beta$-catenin. Decreased expression levels of forkhead box F2 transcription factor and increased mRNA levels of trefoil factor 1, a putative tumor suppressor, were also detected following the silencing of NELF-B. The current results demonstrated that NELF-B enhanced the manifestation of most hallmarks of cancer, including cell proliferation, migration, invasion and inhibition of apoptosis, indicating its critical role in the progression of HCC.

\section{Introduction}

Liver cancer ranks sixth among the most frequently diagnosed types of cancer and fourth among the leading causes of cancer-associated deaths globally, with $\sim 841,000$ newly diagnosed cases and 782,000 deaths reported annually (1). Hepatocellular carcinoma (HCC) is the most prevalent primary liver cancer, accounting for 85-90\% of all liver cancer cases (2). HCC has a poor prognosis, with an average 5-year survival rate of $19.6 \%$, that can be as low as $2.5 \%$ in patients with advanced stages in the United States (3). These low survival rates are attributed to the late diagnosis and limited effectiveness of the current treatment options. Screening of high-risk patients involves the use of non-specific and less-sensitive tools, such as determination of a-fetoprotein serum levels, ultrasound $(4,5)$, expensive imaging techniques, such as computed tomography and magnetic resonance imaging $(6,7)$, and invasive techniques including guided biopsies (8).

Risk factors predisposing individuals to $\mathrm{HCC}$ include hepatitis $\mathrm{B}$ virus (HBV) infection, hepatitis $\mathrm{C}$ virus infection, aflatoxin and alcohol consumption, which mediate the pathogenesis of HCC through different mechanisms (9). Several molecular alterations have been identified in HCC; these include genetic and epigenetic alterations, which make it a complex and heterogeneous disease (10). The current knowledge of molecular biomarkers that would aid the diagnosis, prognosis and therapy monitoring is insufficient. Therefore, investigations on the mechanisms underlying the development of HCC should provide improved diagnostic and prognostic markers, and should promote the development of targeted therapy. 
Cofactor of BRCA1 (COBRA1) was first identified through yeast two-hybrid screening as a novel BRCA1-interacting protein (11). It was later found to be the same protein identified as negative elongation factor-B (NELF-B), which is one of the four subunits of the NELF complex (12). The NELF complex interacts with other factors to negatively regulate the elongation step in transcription by pausing RNA polymerase II (RNAPII) $(13,14)$. The NELF complex consists of four subunits, namely NELF-A, NELF-B, NELF-C/D and NELF-E (15). NELF-C is similar to NELF-D in structure; both are believed to be translational variants of the same mRNA transcript, and either of them can be involved in the formation of the complex at a given point (12). The complex core is composed of NELF-B and NELF-C/D, which brings the other two subunits together (12). NELF-A includes an RNAPII-binding domain, and NELF-E has an RNA-binding domain $(15,16)$. Along with the NELF-B subunit, all the subunits are required for the assembly of a functional NELF complex (12). In fact, the interdependent manner in which the NELF subunits are regulated has been identified in several studies, revealing that depletion of one of these subunits results in dampening of the protein levels of the remaining subunits (17).

Lacking a DNA-binding domain, NELF-B interacts with other transcription complexes, such as steroid hormone receptors and activator protein-1, to mediate their regulatory functions on gene expression $(18,19)$. Some of these interactions occur through the NELF complex, whereas the mechanisms of others remain unclear.

The involvement of NELF-B in the essential transcription regulation machinery governing several cellular processes suggests its potential role in a disease like cancer. Nonetheless, the role of NELF-B in cancer has been studied only in a few types of cancer. NELF-B was first studied in breast cancer; its tumor suppressor role was demonstrated through in vitro experiments (20-22) and was further confirmed by the low levels observed in breast carcinoma tissues (17). Conversely, NELF-B was found to act as an oncogene in upper gastrointestinal adenocarcinoma, as well as prostate and liver cancer (23-25). The diverse effects of NELF-B among different types of cancer are suggestive of the tissue/context-dependent roles of NELF-B. We have previously demonstrated the upregulation of NELF-B in HCC tissue samples compared with its expression in adjacent non-cancerous liver tissues, which is consistent with the in silico analysis of the Oncomine HCC microarray database (25). Subsequent experiments have demonstrated the role of NELF-B in cell proliferation and migration through loss-of-function analyses in HepG2 cells (25), which represents an early stage of liver cancer.

In continuation of our previous work, and to gain further insights into the mechanism underlying the role of NELF-B, the present study involved a gain-of-function analysis in HepG2 cells. To further elucidate the involvement of NELF-B in HCC progression, a loss-of-function analysis was also performed in an intermediate-stage HCC cell line (SNU449) to elucidate the involvement of NELF-B in the progression of HCC.

\section{Materials and methods}

Cell culture. HepG2 and SNU449 cells were generously provided by Dr Mehmet Ozturk, Department of Molecular
Biology and Genetics, Bilkent University, Ankara, Turkey. HepG2 cells represent an early stage of liver cancer and are derived from a well-differentiated tumor from a 15-year-old Caucasian male. HepG2 is classically described as an HCC cell line, but has also been suggested to have originated from hepatoblastoma (26). SNU449 represents an intermediate stage of HCC and is derived from a grade II-III/IV HCC from a 52-year-old Asian male, positive for HBV DNA. The cells were cultured in RPMI-1640 basal medium (Lonza Group, Ltd.) supplemented with 10\% FBS (Invitrogen; Thermo Fisher Scientific, Inc.), $100 \mathrm{U} / \mathrm{ml}$ penicillin and $100 \mathrm{mg} / \mathrm{ml}$ streptomycin (Invitrogen; Thermo Fisher Scientific, Inc.). The cells were incubated in a humidified incubator at $37^{\circ} \mathrm{C}$ with $5 \% \mathrm{CO}_{2}$. Images were captured using an inverted fluorescence phase contrast microscope at x100, x200 or x400 magnifications (Olympus IX70; Olympus Corporation); some images were converted to grey-scale and were adjusted for brightness.

Plasmid constructs. The NELF-B overexpression plasmid, pCMV5-HCOBRA1, was a generous gift from Dr Rong Li, University of Texas Health Science Center, San Antonio TX, USA. An empty pCMV5 plasmid was used as a negative control. Briefly, pCMV5-HCOBRA1 was digested with EcoRI and SalI (New England Biolabs, Inc.). The empty vector $(4.7 \mathrm{~Kb})$ was purified using the QIAquick Gel Extraction kit (Qiagen Sciences, Inc.), following the manufacturer's protocol. The blunting of the 5'-overhangs resulting from the digestion was performed by filling the ends with the Klenow fragment of DNA polymerase I (New England BioLabs, Inc.). For each $\mu \mathrm{g}$ of DNA, 1 unit of Klenow was added, followed by incubation at $25^{\circ} \mathrm{C}$ for $15 \mathrm{~min}$ and heating at $67^{\circ} \mathrm{C}$ for $20 \mathrm{~min}$. T4 DNA ligase (Promega Corporation) was used to re-ligate the blunted vector. The pEGFP-N1 expression plasmid was used to assess the transfection efficiency. The plasmid was provided by Dr Ahmed Osman, Ain Shams University, Cairo, Egypt, and was initially purchased from Clontech Laboratories, Inc.

NELF-B overexpression. HepG2 cells were transfected using Lipofectamine ${ }^{\circledR} 3000$ (Thermo Fisher Scientific, Inc.) according to the manufacturer's protocol. Briefly, HepG2 cells were cultured in 6-well plates and incubated for $24 \mathrm{~h}$ until they were $70-90 \%$ confluent. Before transfection, $3.75 \mu \mathrm{l}$ Lipofectamine 3000 was added to $125 \mu \mathrm{l}$ Opti-MEM reduced serum medium (Gibco; Thermo Fisher Scientific, Inc.) and the mixture was incubated for $5 \mathrm{~min}$ at room temperature. Meanwhile, $2.5 \mu \mathrm{g}$ of either the NELF-B overexpression plasmid pCMV5-HCOBRA1 or pCMV5 empty plasmid was diluted in a mixture of $125 \mu \mathrm{l}$ Opti-MEM and $5 \mu \mathrm{l}$ Lipofectamine 3000. The two dilutions were mixed and incubated for $20 \mathrm{~min}$ to allow for complex formation. The DNA-Lipofectamine complex $(250 \mu \mathrm{l})$ was then added dropwise to each well containing cells in $2 \mathrm{ml}$ of antibiotic-free medium (RPMI + 10\% FBS). Overexpression efficiency was assessed based on the percentage of green fluorescent cells, as well as the protein and mRNA expression levels of NELF-B following transfection. Transfection efficiency was measured 24 and 48 h post-transfection, and was found to be 45 and $60 \%$, respectively using an inverted fluorescence phase contrast microscope at x100 magnification (Fig. S1). At 48 h, NELF-B expression in HepG2 cells transfected with the NELF-B 
A
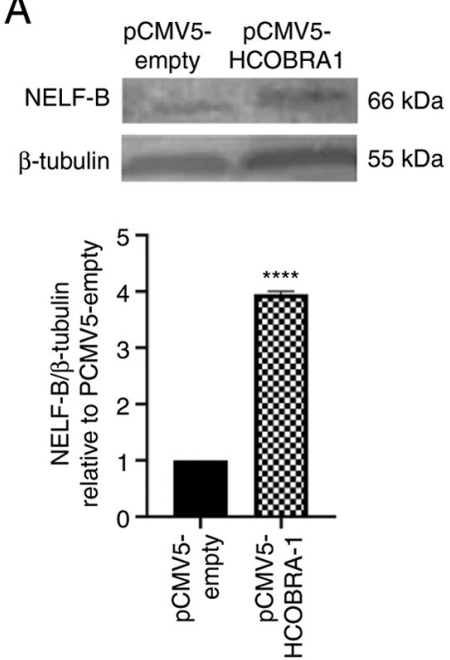

B

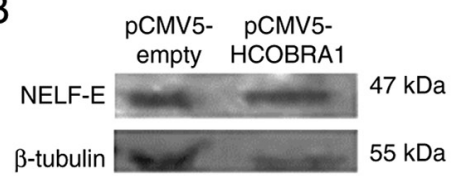

C
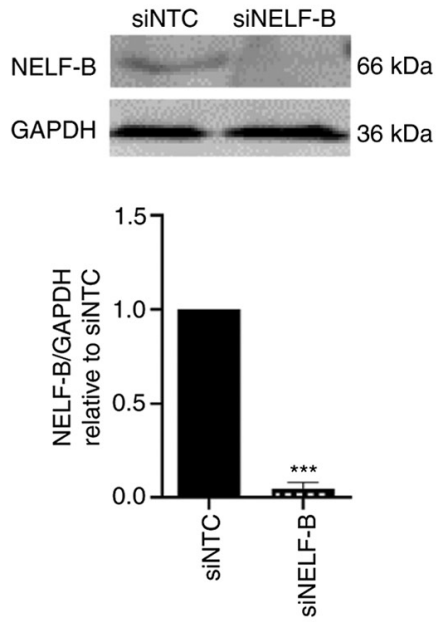
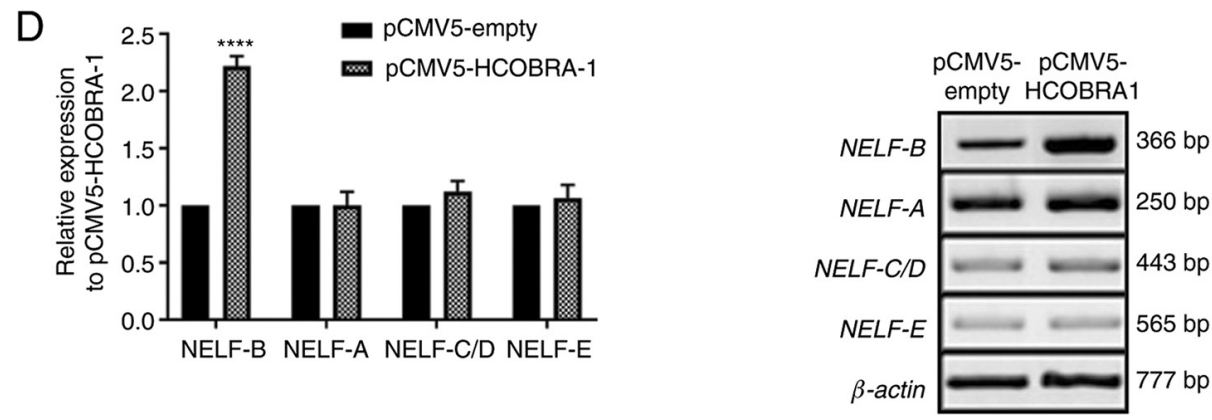

E
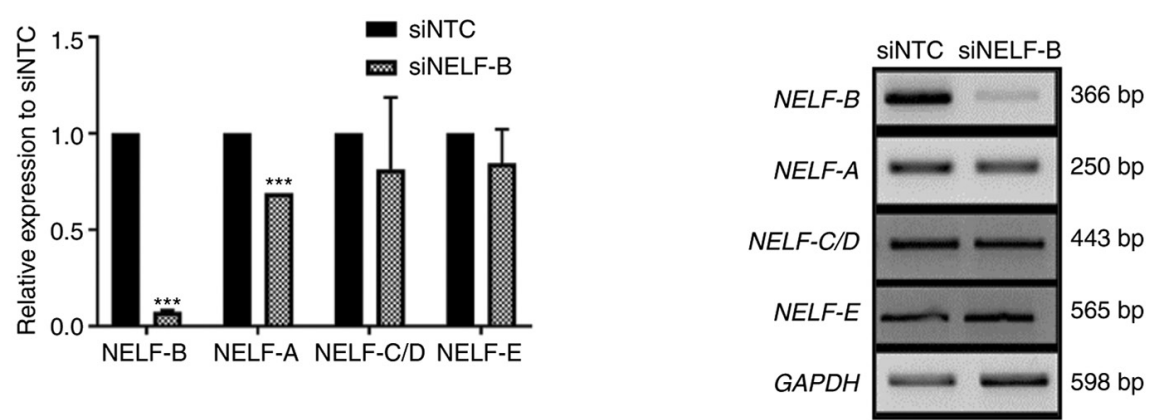

Figure 1. Effects of overexpression and knockdown of NELF-B on the expression levels of NELF subunits. Representative western blots showing the relative expression levels of (A) NELF-B and (B) NELF-E in HepG2 cells following NELF-B overexpression ( $\mathrm{n}=3$ ), and of (C) NELF-B in SNU449 cells following NELF-B-knockdown $(n=2)$. Relative mRNA expression levels of NELF-A, NELF-C/D and NELF-E $(n=3)$ as assessed by reverse transcription-semi-quantitative PCR showing (D) no significant change following the overexpression of NELF-B in HepG2 cells, whereas (E) NELF-A exhibited decreased expression post-NELF-B-knockdown in SNU449 cells $(\mathrm{n}=2)$. ${ }^{* * * *} \mathrm{P} \leq 0.001$ and ${ }^{* * * * * *} \mathrm{P} \leq 0.0001$ vs. pCMV5-empty or siNTC. NELF, negative elongation factor; COBRA1, cofactor of BRCA1; pCMV5-empty, empty pCMV5 vector; pCMV5-HCOBRA1, NELF-B overexpression vector; siRNA, small interfering RNA; siNTC, negative control siRNA; siNELF-B, NELF-B siRNA.

overexpression plasmid (pCMV5-HCOBRA1) was increased 4-fold compared with that in cells transfected with pCMV5 empty plasmid ( $\mathrm{P} \leq 0.0001 ;$ Fig. 1A). The cells were collected $48 \mathrm{~h}$ post-transfection for downstream analysis.

Gene silencing. siGENOME SMARTPool siRNA (cat. no. M-015839-02; GE Healthcare Dharmacon, Inc.), a pool of four siRNAs targeting different exons of the NELF-B mRNA, was used for the knockdown of NELF-B. Allstars' negative control siRNA (cat. no. SI03650318; Qiagen, Inc.) was used as a control. Approximately $1.5 \times 10^{5}$ cells suspended in antibiotic-free medium (RPMI + 10\% FBS) were mixed with the transfection complex prior to seeding (reverse transfection). The complex was prepared by adding $40 \mathrm{nM}$ siRNA and $3.75 \mu \mathrm{l}$ Lipofectamine 3000 to $500 \mu \mathrm{l}$ Opti-MEM medium, followed by incubation for 15-20 min at room temperature. The medium was changed $24 \mathrm{~h}$ after transfection, and fresh antibiotic-free medium (RPMI $+10 \%$ FBS) was added. The optimum knockdown conditions were determined by performing the transfection using different siRNA concentrations $(25$ and $40 \mathrm{nM})$ and post-transfection incubation time points ( 48,72 and $96 \mathrm{~h}$ ) (data not shown). The use of $40 \mathrm{nM}$ siRNA, and an incubation of $96 \mathrm{~h}$ after transfection, resulted in a decrease in the protein levels of NELF-B by an average of $96 \%$ ( $\mathrm{P} \leq 0.001$; Fig. 1C), which 
Table I. Reverse transcription-semi-quantitative PCR primer sequences, PCR conditions and amplicon sizes.

\begin{tabular}{|c|c|c|c|}
\hline Gene & Primer sequence $\left(5^{\prime}-3^{\prime}\right)$ & $\begin{array}{c}\text { PCR conditions } \\
\text { (annealing temperature, number of cycles) }\end{array}$ & $\begin{array}{l}\text { Amplicon } \\
\text { size, bp }\end{array}$ \\
\hline GAPDH & $\begin{array}{l}\text { F: CCACCCATGGCAAATTCCATGGCT } \\
\text { R: TCTAGACGGCAGGTCAGGTCCACC }\end{array}$ & $60.5^{\circ} \mathrm{C}, 26$ cycles & 598 \\
\hline$\beta$-actin & $\begin{array}{l}\text { F: GCAAAGACCTGTACGCCAAC } \\
\text { R: GAGACCAAAAGCCTTCATACATCTC }\end{array}$ & $58^{\circ} \mathrm{C}, 27$ cycles & 777 \\
\hline NELF-B & $\begin{array}{l}\text { F: ACATCACCAAGCAGAGGAA } \\
\text { R: GATCCAGCTGTTCCAGCTTC }\end{array}$ & $59.5^{\circ} \mathrm{C}, 32$ cycles & 366 \\
\hline NELF-A & $\begin{array}{l}\text { F: GTCGGCAGTGAAGCTCAAGT } \\
\text { R: TTCACACTCACCCACCTTTTCT }\end{array}$ & $60^{\circ} \mathrm{C}, 32$ cycles & 250 \\
\hline NELF-C/D & $\begin{array}{l}\text { F: GAAGAAGGAGAGACCCCAGC } \\
\text { R: GTGCCCAAGGCTAGTGTGAT }\end{array}$ & $56^{\circ} \mathrm{C}, 28$ cycles & 443 \\
\hline NELF-E & $\begin{array}{l}\text { F: TGGTGAAGTCAGGAGCCATCAG } \\
\text { R: CGCCGTTCAGGGAATGAATC }\end{array}$ & $63^{\circ} \mathrm{C}, 28$ cycles & 565 \\
\hline Ki67 & $\begin{array}{l}\text { F: CTTTGGGTGCGACTTGACG } \\
\text { R: GTCGACCCCGCTCCTTTT }\end{array}$ & $60^{\circ} \mathrm{C}, 27$ cycles & 199 \\
\hline $\begin{array}{l}\text { Survivin } \\
(\mathrm{BIRC} 5)\end{array}$ & $\begin{array}{l}\text { F: TTGAATCGCGGGACCCGTTGG } \\
\text { R: CAGAGGCCTCAATCCATGGCA }\end{array}$ & $61^{\circ} \mathrm{C}, 28$ cycles & 477 \\
\hline TFF1 & $\begin{array}{l}\text { F: TTTGGAGCAGAGAGGAGGCAATGG } \\
\text { R: TGGTATTAGGATAGAAGCACCAGGG }\end{array}$ & $50^{\circ} \mathrm{C}, 32$ cycles & 240 \\
\hline TFF3 & $\begin{array}{l}\text { F: GTGCCAGCCAAGGACAG } \\
\text { R: CGTTAAGACATCAGGCTCCAG }\end{array}$ & $58^{\circ} \mathrm{C}, 35$ cycles & 302 \\
\hline
\end{tabular}

F, forward; R, reverse; NELF, negative elongation factor; TFF, trefoil factor.

was considered to be the optimal knockdown. The cells were collected $96 \mathrm{~h}$ following transfection for downstream analysis.

Trypan blue exclusion test. Cell viability was determined using the trypan blue exclusion assay (27). HepG2 cells were harvested and counted $48 \mathrm{~h}$ post-transfection to monitor the effect of NELF-B overexpression on cell proliferation. For monitoring the effect of NELF-B silencing on cell proliferation, the number of SNU449 cells was counted $96 \mathrm{~h}$ post-transfection. Cells were mixed with $0.4 \%$ trypan blue in PBS at a ratio of 1:1, and viable cells were counted using a hemocytometer (Hausser Scientific) and an inverted fluorescence phase contrast microscope at x200 magnification.

Reverse transcription-PCR (RT-PCR). TRIzol ${ }^{\circledR}$ reagent (Invitrogen; Thermo Fisher Scientific, Inc.) was used for extraction of total RNA, according to the manufacturer's recommendations. RevertAid First Strand cDNA synthesis kit (Thermo Fisher Scientific, Inc.) was used for cDNA synthesis, following the manufacturer's protocol. Random primers were used for reverse transcription of $0.5 \mu \mathrm{g}$ of the total RNA in a final volume of $20 \mu \mathrm{l}$. MyTaq DNA Polymerase kit (Bioline; Meridian Bioscience) was used for semi-quantitative RT-PCR using $1 \mu \mathrm{l}$ cDNA, according to the manufacturer's recommendations. All the genes were analyzed under similar PCR conditions, except for the cycle number and annealing temperature (Table I). Initial denaturation was performed at $94^{\circ} \mathrm{C}$ for $3 \mathrm{~min}$, followed by cycles of $94^{\circ} \mathrm{C}$ for $30 \mathrm{sec}$, annealing temperature for $30 \mathrm{sec}$ and $72^{\circ} \mathrm{C}$ for $45 \mathrm{sec}$, and a final extension at $72^{\circ} \mathrm{C}$ for $7 \mathrm{~min}$. Amplicons were electrophoresed on a $2-2.5 \%$ agarose gel and visualized using the Gel Doc EZ System (Bio-Rad Laboratories, Inc.). Intensities of bands generated in RT-PCR were quantified using ImageJ software version $1.51 \mathrm{j} 8$ (National Institutes of Health) (28). The band intensities were normalized to those of respective loading controls (GAPDH or $\beta$-tubulin). Images were converted to grey scale.

Quantitative PCR ( $q P C R)$. qPCR amplification was performed using SYBR-Green as a DNA-specific binding dye, and continuous monitoring of fluorescence was done. Each PCR reaction $(10 \mu \mathrm{l})$ consisted of $2 \mathrm{X}$ SYBR-Green I Master Mix (Applied Biosystems; Thermo Fisher Scientific, Inc.), $1 \mu 1$ cDNA and $0.5 \mu 1$ each primer. All the primers used for the selected genes are listed in Table II. The thermal cycler was set up for 40 cycles of the following amplification program: $50^{\circ} \mathrm{C}$ for $2 \mathrm{~min}, 95^{\circ} \mathrm{C}$ for $2 \mathrm{~min}, 95^{\circ} \mathrm{C}$ for $15 \mathrm{sec}$ and $60^{\circ} \mathrm{C}$ for $1 \mathrm{~min}$. The instrument was set to perform the default dissociation step under the following conditions: $95^{\circ} \mathrm{C}$ for $15 \mathrm{sec}, 60^{\circ} \mathrm{C}$ for $1 \mathrm{~min}$ and $95^{\circ} \mathrm{C}$ for $15 \mathrm{sec}$. All experiments were performed three times using the 7500 Real-Time PCR System (Applied Biosystems; Thermo Fisher Scientific, Inc.). Data analysis was performed using the $2^{-\Delta \Delta \mathrm{Cq}}$ method (29) with GAPDH used as the reference gene.

Western blot analysis. Cells were washed with ice-cold PBS before being lysed in $1 \mathrm{X}$ ice-cold Laemmli Lysis Buffer (50 mM Tris pH 6.8, 2\% SDS and 10\% glycerol) supplemented 
Table II. Quantitative PCR primer sequences and amplicon sizes.

\begin{tabular}{|c|c|c|}
\hline Gene & Primer sequence (5'-3') & Amplicon size, bp \\
\hline \multirow[t]{2}{*}{ GAPDH } & F: AAGGTCATCCCTGAGCTGAAC & 142 \\
\hline & R: ACGCCTGCTTCACCACCTTCT & \\
\hline \multirow[t]{2}{*}{ Ki67 } & F: CTTTGGGTGCGACTTGACG & 199 \\
\hline & R: GTCGACCCCGCTCCTTTT & \\
\hline \multirow[t]{2}{*}{ N-cadherin } & F: GCGTCTGTAGAGGCTTCTGGT & 173 \\
\hline & R: TCTGCAGGCTCACTGCTCTC & \\
\hline \multirow[t]{2}{*}{ Vimentin } & F: CTCAATCGGCGGGACAGCAG & 193 \\
\hline & R: GACACGGACCTGGTGGACAT & \\
\hline \multirow[t]{2}{*}{$\beta$-catenin } & F: GAGGAGCAGCTTCAGTCCCC & 139 \\
\hline & R: GCCATTGTCCACGCTGGATT & \\
\hline \multirow[t]{2}{*}{ FOXF2 } & F: AATGCCACTCGCCCTACAC & 199 \\
\hline & R: GGCAGTCCCACTGAGAGGTC & \\
\hline
\end{tabular}

F, forward; R, reverse; FOXF2, forkhead box F2.

with 100X Halt Protease Inhibitor Cocktail (Thermo Fisher Scientific, Inc.; $10 \mu 1$ protease inhibitor per $\mathrm{ml}$ of Laemmli Lysis buffer was used). Protein concentrations were determined using the BCA Protein Assay kit (Pierce; Thermo Fisher Scientific, Inc.), following the manufacturer's protocol. Whole-cell lysates (20-30 $\mu \mathrm{g} /$ lane) were separated via $10 \%$ SDS-PAGE and the proteins were blotted onto a nitrocellulose membrane. The membranes were blocked in 5\% non-fat dry milk, and then incubated overnight with primary antibodies at $4^{\circ} \mathrm{C}$. Subsequently, the membranes were incubated for $1 \mathrm{~h}$ with the secondary antibody at room temperature. Colorimetric detection of the tested proteins was performed using BCIP/NBT Phosphatase colorimetric substrate (KPL). Primary antibodies used were as follows: Mouse monoclonal anti-GAPDH (Abcam; cat. no. ab8245; 1:10,000 in 5\% non-fat dry milk), mouse monoclonal anti- $\beta$-tubulin (Sigma-Aldrich; Merck KGaA; cat. no. T7816; 1:20,000 in 5\% non-fat dry milk), rabbit monoclonal anti-NELF-B (anti-COBRA1; Abcam; cat. no. ab167401; 1:1,000 in 3\% non-fat dry milk) and rabbit monoclonal anti-NELF-E (Abcam; cat. no. ab170104; 1:1,000 in $5 \%$ non-fat dry milk). Secondary antibodies used were polyclonal goat anti-mouse (KPL; cat. no. 4751-1806; 1:10,000 in 5\% non-fat dry milk) and polyclonal goat anti-rabbit (KPL; cat. no. 4751-1516; 1:10,000 in 5\% non-fat dry milk), both have alkaline phosphatase conjugates. For all purposes, non-fat dry milk used in western blot analysis was dissolved in $1 \mathrm{X}$ TBS-0.1\% Tween-20. Intensities of bands generated were quantified using ImageJ software version 1.51 j8 (National Institutes of Health) (28). The band intensities were normalized to those of respective loading controls (GAPDH or $\beta$-tubulin).

Wound healing assay. Classic wound healing assay (30) was performed to assess the effect of the overexpression/knockdown of NELF-B on the cell migration rate. After $48 \mathrm{~h}$ from NELF-B overexpression, and $96 \mathrm{~h}$ post-NELF-B silencing, the spent medium was discarded, a scratch was made in the confluent ( $90 \%)$ cell monolayer using a sterile $20 \mu$ l yellow tip. The cells were gently washed twice with PBS and incubated for $24 \mathrm{~h}$ in fresh $10 \%$ FBS RPMI medium. The migration of cells was monitored using an inverted fluorescence phase contrast microscope at x100 magnification (Olympus IX70; Olympus Corporation); images were converted to greyscale. The wound area was measured using the TScratch software version 1.0 (31), and the percentage of wound closure was calculated using the following equation (32):

$$
W C \%=\frac{W A 0 h-W A 24 h}{W A 0 h} \times 100
$$

where $W C \%$ is the percentage of wound closure, WA $O h$ is the wound area at $0 \mathrm{~h}$, and WA $24 \mathrm{~h}$ is the wound area at $24 \mathrm{~h}$.

Transwell invasion assay. Transwell Boyden 24-well chambers (ThinCert ${ }^{\mathrm{TM}}$; Greiner Bio-One) were used to determine the effect on the invasive capacity of cells. Cells were harvested $96 \mathrm{~h}$ post-transfection, and $2 \times 10^{5}$ cells were suspended in $100 \mu$ RPMI-1640 medium (supplemented with 1\% FBS) and seeded in the upper chamber of the Transwell cell culture insert (8- $\mu \mathrm{m}$ pore size). The cell culture insert was coated with $40 \mu \mathrm{g}$ collagen I (SERVA Electrophoresis GmbH; cat. no. 47254), allowed to dry overnight in an incubator at $37^{\circ} \mathrm{C}$, and rehydrated with $1 \%$ FBS-containing medium, $30 \mathrm{~min}$ before the seeding of cells. The lower chamber was filled with $600 \mu$ l RPMI-1640 medium supplemented with $10 \%$ FBS. Cells were placed inside the upper chamber and incubated for $22 \mathrm{~h}$ at $37^{\circ} \mathrm{C}$. Subsequently, cotton swabs were used to remove cells on the upper side of the membrane, and the cells that invaded to the lower side of the membrane were fixed using $4 \%$ formaldehyde for $10 \mathrm{~min}$ at room temperature, and subsequently stained with DAPI for $10 \mathrm{~min}$ at room temperature in the dark (KPL, Inc.; cat. no. 71-03-01; 1:1,000 in PBS). The images were captured with a fluorescence microscope at $\mathrm{x} 200$ magnification in five random fields for each condition, and the average of cell counts was compared.

Statistical analysis. Relative gene expression was calculated in reference to the negative control siRNA or pCMV5-empty and represented as fold-change. Data are presented as the 
mean \pm SD of two to four independent experiments. Statistical significance for comparison between two groups was performed using unpaired Student's t-test (two-tailed). GraphPad Prism 8.0 (GraphPad Software, Inc., La Jolla California USA) was used to generate graphs. $\mathrm{P}<0.05$ was considered to indicate a statistically significant difference.

\section{Results}

NELF-B-knockdown significantly decreases NELF-A expression in SNU449 cells. Downregulation of NELF-B in the early-stage liver cancer HepG2 cell line has been previously shown to inhibit the migration and proliferation of the cells (25). To investigate whether ectopic expression of NELF-B in the same cell line would lead to an opposite effect to that induced by its downregulation, NELF-B was overexpressed in HepG2 cells. To further investigate the role of NELF-B in the progression of liver cancer, loss of function analysis was performed on the intermediate-stage HCC cell line, SNU449. The efficiency of overexpression and knockdown was assessed by measuring the protein expression levels by western blot analysis. HepG2 cells transfected with the NELF-B overexpression plasmid (pCMV5-HCOBRA1) exhibited a 4-fold increase in NELF-B expression compared with the pCMV5-empty-transfected control cells ( $\mathrm{P} \leq 0.0001$; Fig. 1A); however, NELF-E expression was not significantly altered upon overexpression of NELF-B in HepG2 cells ( $\mathrm{P}>0.05$; Fig. 1B). SNU449 cells transfected with NELF-B siRNA showed a significant decrease in protein expression by an average of $96 \%$ compared with that in the negative siRNA-transfected control cells ( $\mathrm{P} \leq 0.001$; Fig. 1C). Consistent with the protein expression levels, the mRNA expression levels of NELF-B assessed by RT-PCR exhibited a 2.2-fold increase in HepG2 cells following NELF-B overexpression and an average of $93.5 \%$ decrease in SNU449 cells following NELF-B-knockdown compared with their respective controls ( $\mathrm{P} \leq 0.0001$ and $\mathrm{P} \leq 0.001$; Fig. $1 \mathrm{D}$ and $\mathrm{E})$.

The effect of overexpression and knockdown of NELF-B on the expression levels of other NELF subunits was assessed using RT-PCR. The expression levels of NELF-A, NELF-C/D and NELF-E were not significantly affected following the overexpression of NELF-B (P>0.05, Fig. 1D). In SNU449 cells, the expression levels of NELF-C/D and NELF-E were not significantly altered, while NELF-A expression was significantly decreased by an average of $30 \%$ upon knockdown of NELF-B (P $\leq 0.001$; Fig. 1E).

NELF-B-knockdown suppresses cell proliferation and expression of the proliferation marker, Ki67, in SNU449 cells. No morphological changes were observed after the overexpression or knockdown of NELF-B compared with the control cells (Fig. 2A and B). However, cells in which NELF-B was knocked down appeared less dense than their negative controls, suggesting a decrease in the proliferation rate and/or survival of cells (Fig. 2B). To further examine the effect of deregulation of NELF-B on cell proliferation, cells were counted at time points when optimum overexpression/knockdown was observed post-transfection (48 and $96 \mathrm{~h}$ for HepG2 and SNU449 cells, respectively). The count of NELF-B-overexpressing HepG2 cells was similar to that of cells transfected with the empty vector, and no significant difference in Ki-67 mRNA expression was observed ( $\mathrm{P}>0.05$; Fig. 2C). By contrast, the cell count was significantly decreased upon silencing of NELF-B in SNU449 by an average of 58\% compared with the negative control ( $\mathrm{P} \leq 0.001$; Fig. 2D). Consistent with these results, a significant decrease in the expression levels of the proliferation marker, Ki67 (by an average of 51\%), compared with the negative control was also observed ( $\mathrm{P} \leq 0.05$; Fig. $2 \mathrm{D}$ ).

NELF-B-knockdown significantly inhibits the migration and invasion of SNU449 cells. Cancer progression involves epithelial-mesenchymal transition (EMT), a process during which the migratory and invasive abilities of cells increase (33). The present study investigated the association between NELF-B and EMT in liver cancer. Wound healing assay was used to examine the effect of overexpression and knockdown of NELF-B on cell migration. Scratches were made in cell monolayers, 48 and $96 \mathrm{~h}$ post-transfection in HepG2 and SNU449 cells, respectively, and wound closure was monitored $24 \mathrm{~h}$ later. The overexpression of NELF-B in HepG2 cells resulted in a 1.4-fold higher migration rate compared with that in the negative control group; however, the difference was not statistically significant ( $P>0.05$; Fig. $3 \mathrm{~A})$. In SNU449 cells, knockdown of NELF-B significantly decreased the cell migration rate by an average of $49 \%$ compared with that in the negative control group ( $\mathrm{P} \leq 0.001$; Fig. 3B).

Transwell invasion assay was performed to assess the effect of NELF-B-knockdown on the invasive capacity of cells through the extracellular matrix equivalent collagen. The knockdown of NELF-B significantly decreased the number of cells that invaded through collagen by an average of $30 \%$ compared with the control ( $\mathrm{P} \leq 0.01$; Fig. $3 \mathrm{C})$.

NELF-B-knockdown decreases the expression levels of FOXF2 and the EMT markers $N$-cadherin, vimentin and $\beta$-catenin, in SNU449 cells. RT-qPCR was used to assess some of the primary EMT markers, including N-cadherin, vimentin and $\beta$-catenin (34), in SNU449 cells following NELF-B-knockdown. In line with the results of invasion and migration assays, the expression levels of $\mathrm{N}$-cadherin and vimentin were significantly decreased by an average of 75 and $70 \%$, respectively, compared with the negative control ( $\mathrm{P} \leq 0.01$; Fig. 3D). Another critical gene involved in EMT is the signal transducer molecule, $\beta$-catenin. $\beta$-catenin expression is usually elevated in cancer and the protein is localized in the nucleus, where it drives the expression of downstream genes involved in the EMT process (35-37). A significant decrease was observed in the expression levels of $\beta$-catenin post-NELF-B-knockdown by an average of $85 \%$ ( $\mathrm{P} \leq 0.05$; Fig. 3D). The expression levels of the transcription factor FOXF2 were also analyzed, which is reported to enhance the invasion and migration of HCC cells (38). FOXF2 expression was significantly decreased by an average of $60 \%$ following

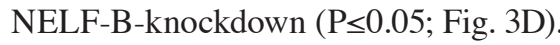

NELF-B-knockdown decreases survivin gene expression and induces apoptosis in SNU449 cells. To examine whether NELF-B affected apoptosis in liver cancer, the mRNA expression levels of survivin were measured, which is known to be deregulated in cancer and serves critical roles in the survival and proliferation of cancer cells (39). The expression levels 
A

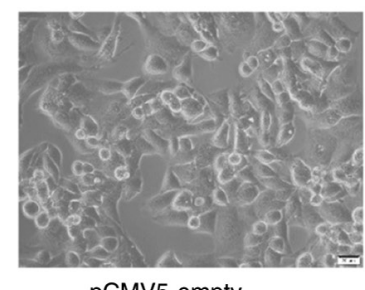

pCMV5-empty

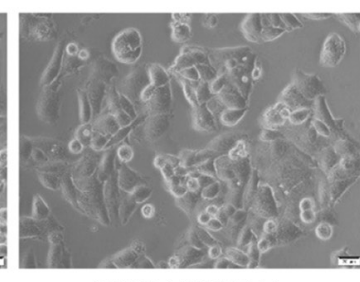

pCMV5-HCOBRA1
B

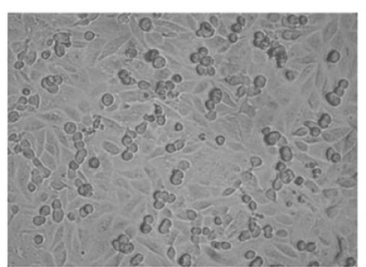

siNTC

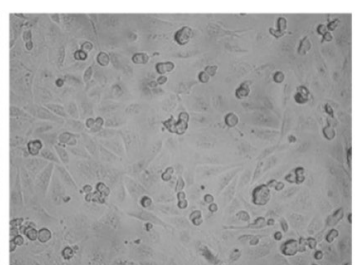

SiNELF-B
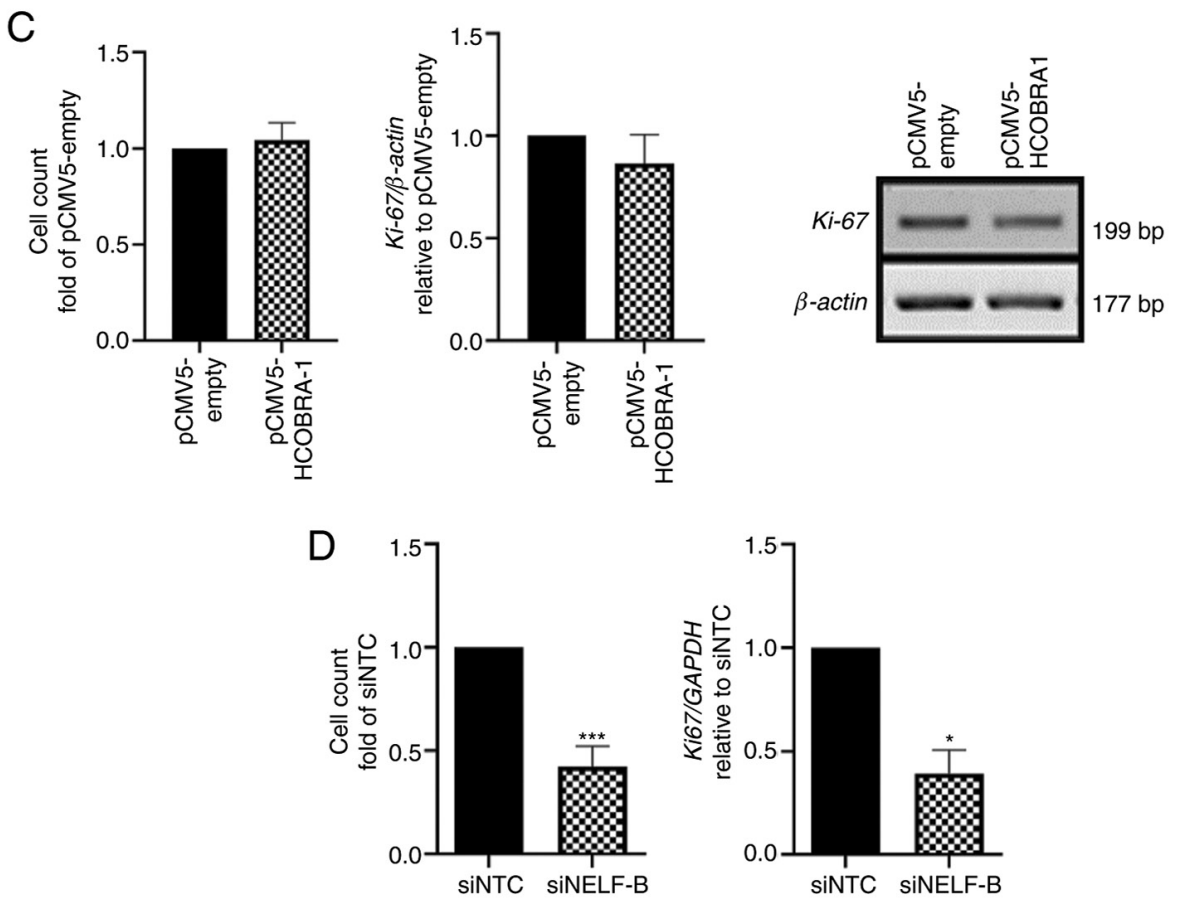

Figure 2. Changes in the proliferation and morphology of cells. (A) No change was observed in the morphology of cells following overexpression of NELF-B in HepG2 cells. Images were obtained using a fluorescence microscope at x400 magnification. (B) In SNU449 cells, no change in morphology was observed in NELF-B-knockdown cells, but the cells were less dense, suggesting a decrease in cell number. Images were obtained using a fluorescence microscope at 200 magnification. (C) Cell counts of HepG2 cells did not change after the overexpression of NELF-B and the relative mRNA expression levels of Ki67 assessed by reverse transcription-semi-quantitative PCR exhibited no significant change (n=3). (D) A significant decrease in cell counts was observed after the knockdown of NELF-B. Data presented as fold-change with respect to the siNTC $(n=4)$. Relative Ki67 mRNA expression as assessed by reverse transcription-quantitative PCR exhibited decreased expression after the knockdown of NELF-B $(n=3)$. ${ }^{*} \leq 0.05$ and ${ }^{* * *} \mathrm{P} \leq 0.001$ vs. siNTC. NELF, negative elongation factor; COBRA1, cofactor of BRCA1; siRNA, small interfering RNA; pCMV5-empty, empty pCMV5 vector; pCMV5-HCOBRA1, NELF-B overexpression vector; siNTC, negative control siRNA; siNELF-B, NELF-B siRNA.

of wild-type survivin have been previously shown to be decreased upon knockdown of NELF-B in HepG2 cells (25). In the present study, the mRNA expression levels of survivin were examined following the overexpression and knockdown of NELF-B. No significant difference in survivin expression was detected upon overexpression of NELF-B in HepG2 cells ( $\mathrm{P}>0.05$; Fig. 4A). By contrast, survivin expression was decreased by an average of $43 \%$ following silencing of NELF-B in SNU449 cells ( $\mathrm{P} \leq 0.05$; Fig. 4B).

DAPI staining revealed fragmented nuclei in cells in which NELF-B was silenced (Fig. 4D). Fragmented nuclei are considered a marker for apoptosis (40), which is in agreement with the decreased survivin expression and decrease in cell counts.

NELF-B silencing decreases trefoil factor 1 (TFF1) expression in SNU449 cells. Several types of cancer, such as breast, gastric, prostate and colorectal cancers exhibit aberrant expression levels of trefoil factor family members, such as TFF1 and TFF3 (41-45). In HCC, the downregulation of TFF1 and the upregulation of TFF3 are frequently observed $(46,47)$. In the present study, the mRNA expression levels of these genes were assessed after knockdown of NELF-B in SNU449 cells. A significant increase of 1.67 fold was observed in the expression levels of TFF1 ( $\mathrm{P} \leq 0.01$; Fig. 4C), while TFF3 expression was decreased by an average of $21 \%$ ( $\mathrm{P}>0.05$, Fig. 4C) compared with the negative control group. Notably, the overexpression of NELF-B in HepG2 cells did not significantly alter the expression levels of either of these genes (data not shown).

\section{Discussion}

The potential role of NELF-B in the pathogenesis of liver cancer has been previously shown $(25,48)$. NELF-B expression has been reported to be upregulated in HCC tissue samples compared with that in paired non-neoplastic tissues (25). In addition, NELF-B has been shown to aid the proliferation and migration in the early stage liver cancer cell line, HepG2 (25). Furthermore, the differential expression of NELF-B has been examined among different liver cancer cell lines, representing 
A
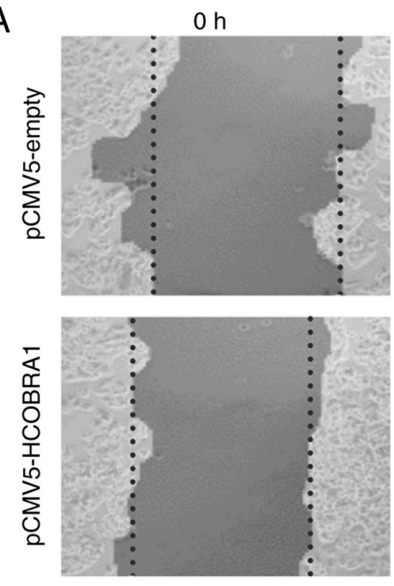

B
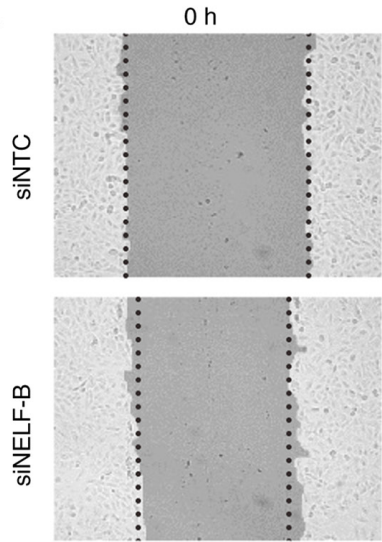

C

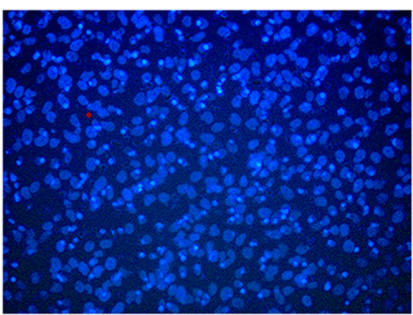

SiNTC
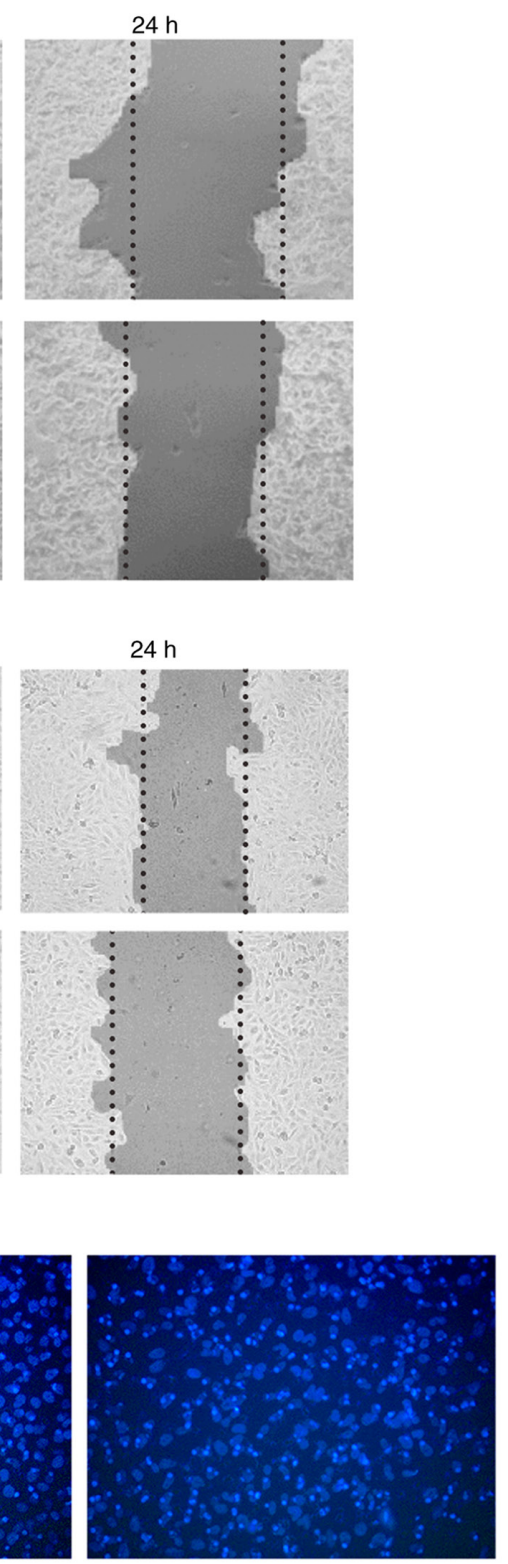

SiNELF-B
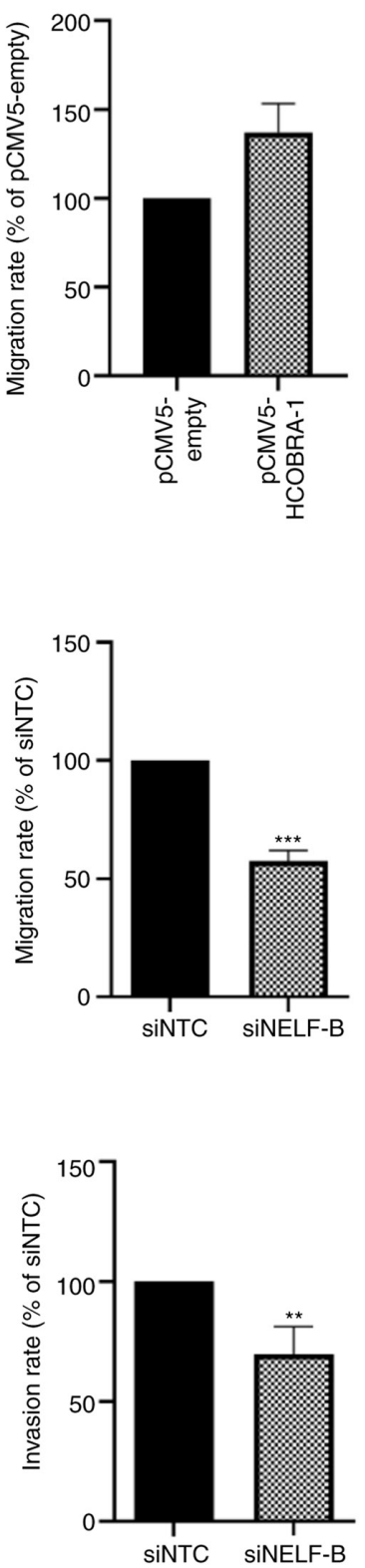

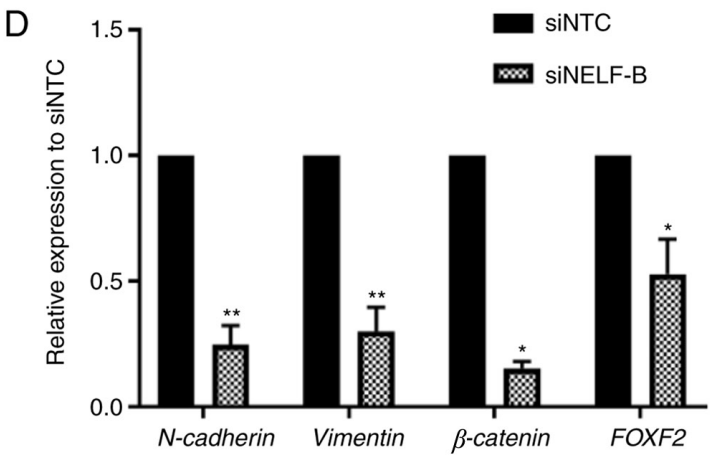

Figure 3. NELF-B-knockdown inhibits the migration and invasion of SNU449 cells. Wound healing assay was performed to evaluate the effect of the overexpression and knockdown of NELF-B on cell migration. (A) No significant changes in the wound healing rate were measured for HepG2 cells following overexpression of NELF-B ( $n=3$ ). (B) Wound healing rate decreased significantly after the knockdown of NELF-B in SNU449 cells ( $\mathrm{n}=3$ ). Images were captured using a phase contrast microscope at x100 magnification at 0 and $24 \mathrm{~h}$ following the scratching. Data are presented as percentages of the migration rate in the negative control. Contrast in the images was automatically generated by TScratch software. (C) Transwell assay to evaluate cell invasion after the knockdown of NELF-B in SNU449 cells revealed a significant decrease in the number of invading cells ( $\mathrm{n}=3$ ). Images were taken using a fluorescence microscope at x200 magnification. Data are presented as percentages of the invasion rate in the negative control. (D) Effect of knockdown of NELF-B on the relative mRNA expression levels of $\mathrm{N}$-cadherin, $\beta$-catenin, vimentin and FOXF2 as assessed by reverse transcription-quantitative PCR ( $\mathrm{n}=3$ for all genes, but $\mathrm{n}=2$ for $\beta$-catenin). ${ }^{*} \mathrm{P} \leq 0.05,{ }^{* *} \mathrm{P} \leq 0.01$ and ${ }^{* * * *} \mathrm{P} \leq 0.001$ vs. siNTC. NELF, negative elongation factor; COBRA1, cofactor of BRCA1; siRNA, small interfering RNA; pCMV5-empty, empty pCMV5 vector; pCMV5-HCOBRA1, NELF-B overexpression vector; siNTC, negative control siRNA; siNELF-B, NELF-B siRNA. 
A

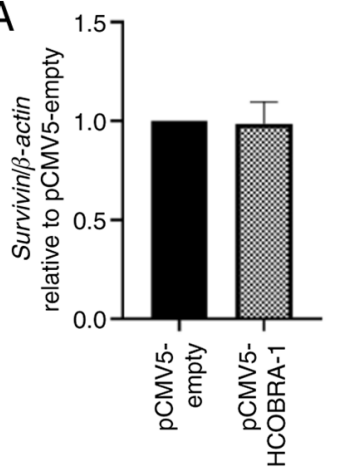

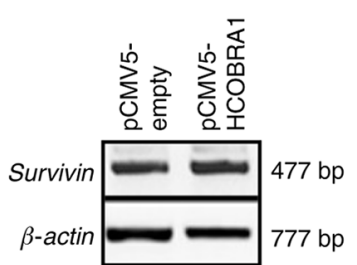

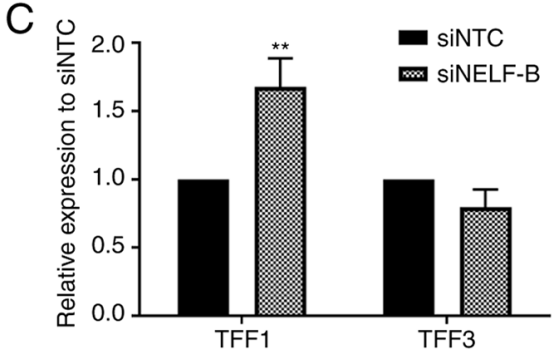

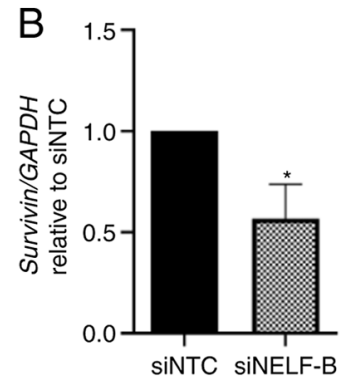

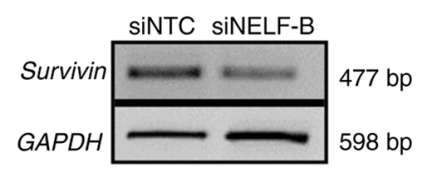

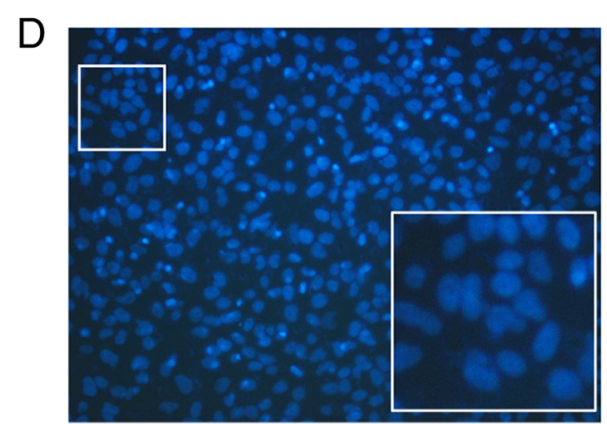

SiNTC
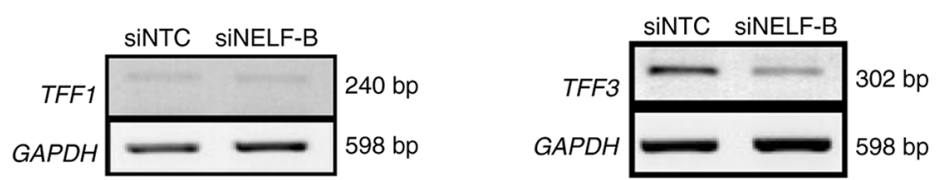

Figure 4. Effect of NELF-B on the expression levels of survivin, TFF1 and TFF3, and on nuclear morphology. Relative mRNA expression levels as assessed by reverse transcription-semi-quantitative PCR for (A) survivin in HepG2 cells after the overexpression of NELF-B and (B) survivin ( $\mathrm{n}=3$ ) and (C) TFF1 and TFF3 $(n=3)$ in SNU449 cells upon NELF-B silencing. (D) Fragmentation of nuclei, considered as a marker of apoptosis, was detected in NELF-B-knockdown cells. Figures show the images at $\mathrm{x} 200$ magnification obtained by fluorescence microscopy in Transwell assay, which were cropped and enlarged 5.5 folds to show the nuclei. ${ }^{*} \mathrm{P} \leq 0.05$ and ${ }^{* *} \mathrm{P} \leq 0.01$ vs. siNTC. NELF, negative elongation factor; COBRA1, cofactor of BRCA1; siRNA, small interfering RNA; pCMV5-empty, empty pCMV5 vector; pCMV5-HCOBRA1, NELF-B overexpression vector; siNTC, negative control siRNA; siNELF-B, NELF-B siRNA.

various stages of liver cancer (48). The results have revealed that NELF-B expression is the highest in the early stages, and decreases gradually with the advance in stage of liver cancer, suggesting a possible involvement of NELF-B in the initiation of liver cancer rather than in its progression (48). The present study aimed to gain further insights into the role of NELF-B through its ectopic expression in HepG2 cells and tried to unravel the underlying mechanism. To investigate the involvement of NELF-B in the maintenance and progression of HCC, a loss-of-function analysis was also performed in SNU449 cells, which represents an intermediate-stage HCC cell line.

Sustenance of cell proliferation is the most fundamental trait of cancer cells (49). In the present study, overexpression of NELF-B did not induce the proliferation of HepG2 cells, as evidenced by cell counting and Ki-67 mRNA expression assays. The migratory ability of NELF-B-overexpressing cells was similar to that of empty plasmid-transfected cells; however, this assay may have been affected by the low initial confluence of the cells. Additionally, NELF-B-overexpressing cells exhibited a non-significant effect on the apoptotic marker, survivin. The current results indicated that overexpression of NELF-B in HepG2 cells did not have an effect opposite to that of its knockdown, which significantly decreased the proliferation and migration potential of HepG2 cells and decreased Ki-67 and survivin expression (25).

In prostate cancer, ectopic expression of NELF-B has been found to support the viability, proliferation and anchorage-independent growth of cells (24). This effect was opposite to that observed following the knockdown of NELF-B (24). In breast cancer, ectopic expression of NELF-B decreased the proliferation of cells, whereas its knockdown led to the enhancement of proliferation (20). The latter study has suggested that NELF-B may act through the NELF complex to repress estrogen receptor $\alpha(E R \alpha)$-mediated transcription and that NELF-B may be a rate-limiting step for enhanced NELF activity in the examined cell line, since its ectopic expression increased NELF-E promoter binding, and the expression of a subset of ER- $\alpha$ responsive genes was subsequently 
repressed (20). On the contrary, the current results indicated that overexpression of NELF-B was inadequate at promoting the proliferation and migration of cells. These results suggest that NELF-B may not be the rate-limiting factor for exerting an effect on the tested cellular features in HepG2 cells, and that it may be acting through the NELF complex, which requires the abundance of other subunits to form a functional complex.

The present study detected similar mRNA expression levels of the NELF subunits and NELF-E protein following the overexpression of NELF-B in HepG2 cells. These results are consistent with previous findings (17), and indicate a tight control on the abundance of the NELF complex in the regular cellular context. The interdependence of the NELF subunits has been shown in different cell types, where the knockdown of one subunit did not affect the mRNA expression levels of other subunits, but resulted in instability of the NELF complex and co-depletion of other subunits at the protein level $(17,50)$. Notably, in the present study, a significant decrease in the mRNA expression levels of NELF-A was detected in NELF-B-silenced SNU449 cells, which has not been previously reported to the best of our knowledge. It would be interesting to further examine the mechanism involved in this regulation.

NELF-B silencing resulted in a significant decrease in cell proliferation, as well as in the mRNA expression levels of $\mathrm{Ki}-67$, which is the most predominantly used proliferation marker (51). These results are consistent with the effect of NELF-B-knockdown in HepG2 cells (25). Inhibition of apoptotic pathways is another main hallmark of cancer, promoting the survival of defective cancer cells (49). BIRC5, also known as survivin, is a member of the inhibitor of apoptosis proteins family, which inhibit apoptosis by binding to caspases (52). The expression of survivin is undetectable or low in normal adult tissues, but the protein is overexpressed in most types of cancer, such as liver, blood and gastric cancers (52-55). Additionally, survivin supports cell cycle progression, counteracts the tumor suppressor retinoblastoma protein and induces angiogenesis (56-58). In the present study, a significant decrease in survivin expression was observed upon knockdown of NELF-B, which is in concordance with the decrease in cell count and the detection of nuclear fragments, which signifies apoptosis (59). This association between survivin expression and NELF-B has been shown in different cancer cell lines, including SNU449, HepG2 (25), cervical cancer HeLa cells (experiments are ongoing) and breast cancer T47D cells (21). This consistent association over different stages and different types of cancer suggests the possibility of a direct regulation that requires to be further examined.

To further understand the involvement of NELF-B in cancer progression, EMT markers were investigated. EMT occurs during cancer progression, allowing metastasis through enhanced migration and invasion of cancer cells (33). Silencing of NELF-B in SNU449 cells resulted in a significant decrease in cell migration, consistent with the findings reported for HepG2 cells (25). Additionally, NELF-B-silenced cells exhibited a decrease in the invasive ability of cells. To the best of our knowledge, the present study demonstrated for the first time that NELF-B supported invasion, in addition to migration, in HCC. Consistently, decreased expression levels of the mesenchymal markers $\mathrm{N}$-cadherin, vimentin and $\beta$-catenin were observed. Vimentin is an intermediate filament that is central to the cytoskeletal structure and cell integrity (60), whereas $\mathrm{N}$-cadherin promotes collective cell migration and modulates the expression of several cancer-associated genes (61). There are contradictory studies regarding the effect of $\mathrm{N}$-cadherin on metastases in HCC, with one study linking its downregulation to enhanced metastasis (62) and another linking overexpression to metastasis (63). $\beta$-catenin, an EMT marker, is a central signal transducer of the canonical Wnt/ $\beta$-catenin signaling pathway $(64,65)$. Although this pathway is vital for the development of normal liver, its aberrant activation is frequently implicated in HCC (66). In the absence of Wnt signaling molecules, the $\beta$-catenin destruction complex is activated, ultimately leading to both phosphorylation and ubiquitination of $\beta$-catenin (67). Upon deactivation of the destruction complex, $\beta$-catenin is accumulated in the cytosol and is eventually translocated to the nucleus, where it binds to $\mathrm{LEF} / \mathrm{TCF}$ factors to regulate the expression of target genes (68-70). It is suggested that $\beta$-catenin, via the Wnt/ $\beta$-catenin signaling pathway, activates the expression of several downstream genes, such as vimentin (71), matrix metalloproteinases (72) and fibronectin (73), which are associated with a mesenchymal phenotype. Additionally, $\beta$-catenin has been reported to be involved in the induction of survivin expression (74).

FOXF2 is another interesting protein associated with EMT. It is a transcription factor with a dual role of promoting or inhibiting proliferation, invasion and metastasis in tumors, depending on the tumor type and subtype (75). In HCC, the downregulation of FOFX2 induces mesenchymal-epithelial transition and inhibits the invasion and migration of HCC cells (38), which is in accordance with the concomitant decrease of FOXF2 expression, invasion and migration in NELF-B-silenced cells observed in the present study. The downregulation of FOXF2 promotes the proliferation of Huh7 cells, which represent well-differentiated HCC $(76,77)$. Nonetheless, in SNU449 cells, decreased FOXF2 expression was accompanied by the inhibition of proliferation, which suggests that the effect of FOXF2 on proliferation is dependent on the context.

NELF is a critical regulator of clustered genes, including those of the trefoil family such as TFF1 and TFF3 (22). The knockdown of NELF-B did not significantly affect the steady-state expression of TFF3 mRNA in SNU449 cells; however, the steady-state expression of TFF1 mRNA was significantly increased. The current results suggested that NELF-B may be implicated in repressing TFF1 expression. TFF1 is encoded by the TFF1 gene and belongs to the trefoil family; this family of secretory proteins characteristically contains at least one trefoil motif (46). Although mainly secreted by gastric epithelial cells, TFF1 is also secreted by hepatic cells, albeit to a lower degree (46). Studies performed in breast cancer and upper gastrointestinal adenocarcinoma have revealed that NELF-B negatively regulates TFF1 $(20,23)$. TFF1 has been shown to function as a protectant and restorer of the gastrointestinal tract, an inflammatory suppressor and a possible regulator of tissue regeneration (78). In HCC, the putative tumor suppressor, TFF1, has been shown to suppress proliferation in HCC cell lines, whereas its deficiency in a TFF knock-out mouse model promoted HCC progression (46). 
Additionally, TFF1 expression has been found to affect the localization of $\beta$-catenin and to negatively regulate its transcriptional activity and downstream targets in both gastric cancer and HCC (46,78). The current results suggested that NELF-B may promote tumorigenesis in SNU449 cells by negatively regulating TFF1 expression. It has been reported that NELF-B represses the expression of specific estrogen-responsive genes, including TFF1, in breast cancer (22). Nevertheless, NELF-B has also been shown to modulate gene expression, independent of Era (23). Therefore, NELF-B may regulate TFF1 expression in either an estrogen-dependent or estrogen-independent manner; however, the exact mechanism by which NELF-B regulates TFF1 in SNU449 cells remains to be determined.

A previous study investigating the role of NELF-E in HCC has shown that NELF-E supports cell proliferation, colony formation, oncosphere formation and cell migration through loss- and gain-of-function analysis (79). The similar effects of NELF-E- and NELF-B-knockdown suggest that NELF-B may mediate its action in HCC predominantly through the NELF complex. Nonetheless, it should be considered that these subunits do not act through NELF exclusively, and further elucidation of additional mechanisms and overlap of their functions is required.

The present study provided evidence that NELF-B served a critical role in the progression of HCC. It supported some of the significant cancer hallmarks, including cell proliferation, apoptosis inhibition and EMT, which is essential for cancer metastasis. The lack of effect on proliferation and migration following ectopic expression in HepG2 cells suggested the insufficiency of NELF-B overexpression in promoting an increase in these processes. NELF-B may have a great potential for use as a prognostic factor and a therapeutic target for liver cancer. Further examination of different etiologies among HCC and more advanced stages is recommended. Additionally, an elucidation of the mechanisms of NELF-B action and its effect on the entire transcriptome would provide valuable insights.

\section{Acknowledgements}

The authors would like to thank Mr. Amged Ouf (The American University in Cairo, New Cairo, Egypt) for his technical support in performing the plasmid transfection experiments, and Mr. Tarek Saleh for his help in generating the figures (Cannonball VFX LLC, San Diego, CA, USA).

\section{Funding}

The present study was supported by the American University in Cairo Internal Faculty Research Grant and Graduate Student Research Grants.

\section{Availability of data and materials}

All data generated or analyzed during this study are included in this published article.

\section{Authors' contributions}

AA conceived and designed the study. AA supervised and contributed to the analysis and troubleshooting of all the experiments and results. RJM performed the overexpression and subsequent functional assays in HepG2. MHG performed the knockdown and subsequent functional assays in SNU449. MHG, RJM, EZM, RZ and AMA performed and interpreted RT-PCR results. OMA performed and interpreted qPCR results. MHG, RJM, EZM and OMA contributed to data analysis. MHG drafted the initial manuscript with outstanding contributions from RJM, EZM and OMA. All authors have read and approved the final manuscript. RJM and AA confirmed the authenticity of the raw data related to NELF-B overexpression. MHG and AA confirmed the authenticity of the raw data associated with the NELF-B knockdown.

\section{Ethics approval and consent to participate}

Not applicable.

\section{Patient consent for publication}

Not applicable.

\section{Competing interests}

The authors declare that they have no competing interests.

\section{References}

1. Bray F, Ferlay J, Soerjomataram I, Siegel RL, Torre LA and Jemal A: Global cancer statistics 2018: GLOBOCAN estimates of incidence and mortality worldwide for 36 cancers in 185 countries. CA Cancer J Clin 68: 394-424, 2018.

2. Simonetti RG, Liberati A, Angiolini C and Pagliaro L: Treatment of hepatocellular carcinoma: A systematic review of randomized controlled trials. Ann Oncol 8: 117-136, 1997.

3. Chidambaranathan-Reghupaty S, Fisher PB and Sarkar D: Hepatocellular carcinoma (HCC): Epidemiology, etiology and molecular classification. Adv Cancer Res 149: 1-61, 2021.

4. Zhao YJ, Ju Q and Li GC: Tumor markers for hepatocellular carcinoma. Mol Clin Oncol 1: 593-598, 2013.

5. Sanyal AJ, Yoon SK and Lencioni R: The etiology of hepatocellular carcinoma and consequences for treatment. Oncologist 15 (Suppl 4): S14-S22, 2010.

6. Dong Y, Wang WP, Mao F, Zhang Q, Yang D, Tannapfel A, Meloni MF, Neye H, Clevert DA and Dietrich CF: Imaging features of fibrolamellar hepatocellular carcinoma with contrast-enhanced ultrasound. Ultraschall Med 42: 306-313, 2021.

7. Jiang HY, Chen J, Xia CC, Cao LK, Duan T and Song B: Noninvasive imaging of hepatocellular carcinoma: From diagnosis to prognosis. World J Gastroenterol 24: 2348-2362, 2018.

8. Andreana L, Isgrò G, Pleguezuelo M, Germani G and Burroughs AK: Surveillance and diagnosis of hepatocellular carcinoma in patients with cirrhosis. World J Hepatol 1: 48-61, 2009.

9. Janevska D, Chaloska-Ivanova V and Janevski V: Hepatocellular carcinoma: Risk factors, diagnosis and treatment. Open Access Maced J Med Sci 3: 732-736, 2015.

10. Dhanasekaran R, Bandoh S and Roberts LR: Molecular pathogenesis of hepatocellular carcinoma and impact of therapeutic advances. F1000Res 5: F1000 Faculty Rev-879, 2016.

11. Ye Q, Hu YF, Zhong H, Nye AC, Belmont AS and Li R: BRCA1-induced large-scale chromatin unfolding and allele-specific effects of cancer-predisposing mutations. J Cell Biol 155: 911-921, 2001

12. Narita T, Yamaguchi Y, Yano K, Sugimoto S, Chanarat S, Wada T, Kim DK, Hasegawa J, Omori M, Inukai N, et al: Human transcription elongation factor NELF: Identification of novel subunits and reconstitution of the functionally active complex. Mol Cell Biol 23: 1863-1873, 2003. 
13. Wada T, Takagi T, Yamaguchi Y, Ferdous A, Imai T, Hirose S, Sugimoto S, Yano K, Hartzog GA, Winston F, et al: DSIF, a novel transcription elongation factor that regulates RNA polymerase II processivity, is composed of human Spt4 and Spt5 homologs. Genes Dev 12: 343-356, 1998.

14. Yankulov K, Yamashita K, Roy R, Egly JM and Bentley DL: The transcriptional elongation inhibitor 5,6-Dichloro-1- $\beta$-D-ribofura nosylbenzimidazole inhibits transcription Factor IIH-associated protein kinase. J Biol Chem 270: 23922-23925, 1995.

15. Yamaguchi Y, Takagi T, Wada T, Yano K, Furuya A, Sugimoto S, Hasegawa J and Handa H: NELF, a multisubunit complex containing RD, cooperates with DSIF to repress RNA polymerase II elongation. Cell 97: 41-51, 1999.

16. Yamaguchi Y, Filipovska J, Yano K, Furuya A, Inukai N, Narita T, Wada T, Sugimoto S, Konarska MM and Handa H: Stimulation of RNA polymerase II elongation by hepatitis delta antigen. Science 293: 124-127, 2001.

17. Sun J, Watkins G, Blair AL, Moskaluk C, Ghosh S, Jiang WG and Li R: Deregulation of cofactor of BRCA1 expression in breast cancer cells. J Cell Biochem 103: 1798-1807, 2008

18. Sun J, Blair AL, Aiyar SE and Li R: Cofactor of BRCA1 modulates androgen-dependent transcription and alternative splicing. J Steroid Biochem Mol Biol 107: 131-139, 2007.

19. Zhong H, Zhu J, Zhang H, Ding L, Sun Y, Huang C and Ye Q COBRA1 inhibits AP-1 transcriptional activity in transfected cells. Biochem Biophys Res Commun 325: 568-573, 2004.

20. Aiyar SE, Sun JL, Blair AL, Moskaluk CA, Lu YZ, Ye QN Yamaguchi Y, Mukherjee A, Ren DM, Handa H and Li R: Attenuation of estrogen receptor alpha-mediated transcription through estrogen-stimulated recruitment of a negative elongation factor. Genes Dev 18: 2134-2146, 2004.

21. Aiyar SE, Cho H, Lee J and Li R: Concerted transcriptional regulation by BRCA1 and COBRA1 in breast cancer cells. Int J Biol Sci 3: 486-492, 2007.

22. Aiyar SE, Blair AL, Hopkinson DA, Bekiranov S and Li R: Regulation of clustered gene expression by cofactor of BRCA1 (COBRA1) in breast cancer cells. Oncogene 26: 2543-2553, 2007.

23. McChesney PA, Aiyar SE, Lee OJ, Zaika A, Moskaluk C, Li R and El-Rifai W: Cofactor of BRCA1: A novel transcription factor regulator in upper gastrointestinal adenocarcinomas. Cancer Res 66: 1346-1353, 2006

24. Yun H, Bedolla R, Horning A, Li R, Chiang HC, Huang TH, Reddick R, Olumi AF, Ghosh R and Kumar AP: BRCA1 interacting protein COBRA1 facilitates adaptation to Castrate-Resistant growth conditions. Int J Mol Sci 19: 2104, 2018.

25. El Zeneini E, Kamel S, El-Meteini M and Amleh A: Knockdown of COBRA1 decreases the proliferation and migration of hepatocellular carcinoma cells. Oncol Rep 37: 1896-1906, 2017.

26. López-Terrada D, Cheung SW, Finegold MJ and Knowles BB Hep G2 is a hepatoblastoma-derived cell line. Hum Pathol 40: 1512-1515, 2009.

27. Strober W: Trypan blue exclusion test of cell viability. Curr Protoc Immunol: doi: 10.1002/0471142735.ima03bs21.

28. Schneider CA, Rasband WS and Eliceiri KW: NIH Image to ImageJ: 25 years of image analysis. Nat Methods 9: 671-675, 2012.

29. Livak KJ and Schmittgen TD: Analysis of relative gene expression data using real-time quantitative PCR and the 2(-Delta Delta $\mathrm{C}(\mathrm{T})$ ) method. Methods 25: 402-408, 2001

30. Jonkman JE, Cathcart JA, Xu F, Bartolini ME, Amon JE Stevens KM and Colarusso P: An introduction to the wound healing assay using live-cell microscopy. Cell Adh Migr 8: 440-451, 2014

31. Gebäck T, Schulz MMP, Koumoutsakos P and Detmar M TScratch: A novel and simple software tool for automated analysis of monolayer wound healing assays. BioTechniques 46 : 265-274, 2009

32. Boleman AI, Tănasie G, Găluscan A, Cristea MI, Bojin FM, Panaitescu $C$ and Păunescu V: Studies regarding the in vitro wound healing potential of mouse dental pulp stem-like progenitor cells. Biotechnol \& Biotec Eq 26: 2781-2785, 2012.

33. Kalluri R and Weinberg RA: The basics of epithelial-mesenchymal transition. J Clin Invest 119: 1420-1428, 2009.

34. Cho SB, Lee KH, Lee JH, Park SY, Lee WS, Park CH, Kim HS Choi SK and Rew JS: Expression of E- and N-cadherin and clinicopathology in hepatocellular carcinoma. Pathol Int 58: 635-642, 2008

35. Dahmani R, Just PA and Perret C: The Wnt// -catenin pathway as a therapeutic target in human hepatocellular carcinoma. Clin Res Hepatol Gastroenterol 35: 709-713, 2011.
36. Khramtsov AI, Khramtsova GF, Tretiakova M, Huo D, Olopade OI and Goss $\mathrm{KH}$ : Wnt//-catenin pathway activation is enriched in basal-like breast cancers and predicts poor outcome. Am J Pathol 176: 2911-2920, 2010.

37. Kobayashi M, Honma T, Matsuda Y, Suzuki Y, Narisawa R, Ajioka $\mathrm{Y}$ and Asakura $\mathrm{H}$ : Nuclear translocation of $\beta$-catenin in colorectal cancer. Br J Cancer 82: 1689-1693, 2000.

38. Dou C, Jin X, Sun L, Zhang B, Han M and Li T: FOXF2 deficiency promotes hepatocellular carcinoma metastasis by inducing mesenchymal-epithelial transition. Cancer Biomark 19: 447-454, 2017.

39. Fukuda $\mathrm{S}$ and Pelus LM: Survivin, a cancer target with an emerging role in normal adult tissues. Mol Cancer Ther 5: 1087-1098, 2006

40. Kerr JF, Wyllie AH and Currie AR: Apoptosis: A basic biological phenomenon with wide-ranging implications in tissue kinetics. Br J Cancer 26: 239-257, 1972.

41. Lacroix M: Significance, detection and markers of disseminated breast cancer cells. Endocr Relat Cancer 13: 1033-1067, 2006

42. Im S, Yoo C, Jung JH, Choi HJ, Yoo J and Kang CS: Reduced expression of TFF1 and increased expression of TFF3 in gastric cancer: Correlation with clinicopathological parameters and prognosis. Int J Med Sci 10: 133-140, 2013.

43. Vestergaard EM, Borre M, Poulsen SS, Nexø E and Tørring N: Plasma levels of trefoil factors are increased in patients with advanced prostate cancer. Clin Cancer Res 12 (3 Pt 1): 807-812, 2006.

44. Yusufu A, Shayimu P, Tuerdi R, Fang C, Wang F and Wang H: TFF3 and TFF1 expression levels are elevated in colorectal cancer and promote the malignant behavior of colon cancer by activating the EMT process. Int J Oncol 55: 789-804, 2019.

45. Casado E, Garcia VM, Sánchez JJ, Gómez Del Pulgar MT, Feliu J, Maurel J, Castelo B, Moreno Rubio J, López RA, García-Cabezas MÁ, et al: Upregulation of trefoil factor 3 (TFF3) after rectal cancer chemoradiotherapy is an adverse prognostic factor and a potential therapeutic target. Int J Radiat Oncol Biol Phys 84: 1151-1158, 2012

46. Ochiai Y, Yamaguchi J, Kokuryo T, Yokoyama Y, Ebata T and Nagino M: Trefoil factor family 1 inhibits the development of hepatocellular carcinoma by regulating $\beta$-catenin activation. Hepatology 72: 503-517, 2020.

47. You ML, Chen YJ, Chong QY, Wu MM, Pandey V, Chen RM, Liu L, Ma L, Wu ZS, Zhu T and Lobie PE: Trefoil factor 3 mediation of oncogenicity and chemoresistance in hepatocellular carcinoma is AKT-BCL-2 dependent. Oncotarget 8: 39323-39344, 2017.

48. Youssef A, Shawer H, Afify A and Amleh A: The potential involvement of the cofactor of BRCA1 in hepatocellular carcinoma pathogenesis. Adv Mod Oncol Res 2: 224, 2016.

49. Hanahan D and Weinberg RA: The hallmarks of cancer. Cell 100: 57-70, 2000.

50. Sun J and Li R: Human negative elongation factor activates transcription and regulates alternative transcription initiation. J Biol Chem 285: 6443-6452, 2010

51. Schlüter C, Duchrow M, Wohlenberg C, Becker MH, Key G, Flad HD and Gerdes J: The cell proliferation-associated antigen of antibody Ki-67: A very large, ubiquitous nuclear protein with numerous repeated elements, representing a new kind of cell cycle-maintaining proteins. J Cell Biol 123: 513-522, 1993.

52. Hunter AM, LaCasse EC and Korneluk RG: The inhibitors of apoptosis (IAPs) as cancer targets. Apoptosis 12: 1543-1568, 2007.

53. Ambrosini G, Adida C and Altieri DC: A novel anti-apoptosis gene, survivin, expressed in cancer and lymphoma. Nat Med 3: 917-921, 1997.

54. Han G,GongH,Wang Y,GuoS andLiu K: AMPK/mTOR-mediated inhibition of survivin partly contributes to metformin-induced apoptosis in human gastric cancer cell. Cancer Biol Ther 16: 77-87, 2015

55. Su C: Survivin in survival of hepatocellular carcinoma. Cancer Lett 379: 184-190, 2016

56. Giodini A, Kallio MJ, Wall NR, Gorbsky GJ, Tognin S, Marchisio PC, Symons M and Altieri DC: Regulation of microtubule stability and mitotic progression by survivin. Cancer Res 62: 2462-2467, 2002

57. Suzuki A, Hayashida M, Ito T, Kawano H, Nakano T, Miura M, Akahane K and Shiraki K: Survivin initiates cell cycle entry by the competitive interaction with Cdk4/p16(INK4a) and Cdk2/cyclin E complex activation. Oncogene 19: 3225-3234, 2000. 
58. O'Connor DS, Schechner JS, Adida C, Mesri M, Rothermel AL, Li F, Nath AK, Pober JS and Altieri DC: Control of apoptosis during angiogenesis by survivin expression in endothelial cells. Am J Pathol 156: 393-398, 2000.

59. Kramer A, Liashkovich I, Oberleithner H, Ludwig S, Mazur I and Shahin V: Apoptosis leads to a degradation of vital components of active nuclear transport and a dissociation of the nuclear lamina. Proc Natl Acad Sci USA 105: 11236-11241, 2008

60. Goldman RD, Khuon S, Chou YH, Opal P and Steinert PM: The function of intermediate filaments in cell shape and cytoskeletal integrity. J Cell Biol 134: 971-983, 1996.

61. Mrozik KM, Blaschuk OW, Cheong CM, Zannettino ACW and Vandyke K: N-cadherin in cancer metastasis, its emerging role in haematological malignancies and potential as a therapeutic target in cancer. BMC Cancer 18: 939, 2018.

62. Zhan DQ, Wei S, Liu C, Liang BY, Ji GB, Chen XP, Xiong M and Huang ZY: Reduced N-cadherin expression is associated with metastatic potential and poor surgical outcomes of hepatocellular carcinoma. J Gastroenterol Hepatol 27: 173-180, 2012.

63. Zhou SJ, Liu FY, Zhang AH, Liang HF, Wang Y, Ma R, Jiang YH and Sun NF: MicroRNA-199b-5p attenuates TGF-betal-induced epithelial-mesenchymal transition in hepatocellular carcinoma. Br J Cancer 117: 233-244, 2017.

64. Noordermeer J, Klingensmith J, Perrimon N and Nusse R: Dishevelled and armadillo act in the Wingless signalling pathway in Drosophila. Nature 367: 80-83, 1994.

65. Peifer M, Berg S and Reynolds AB: A repeating amino acid motif shared by proteins with diverse cellular roles. Cell 76 : 789-791, 1994.

66. Laurent-Puig P and Zucman-Rossi J: Genetics of hepatocellular tumors. Oncogene 25: 3778-3786, 2006.

67. Papkoff J, Rubinfeld B, Schryver B and Polakis P: Wnt-1 regulates free pools of catenins and stabilizes APC-catenin complexes. Mol Cell Biol 16: 2128-2134, 1996.

68. Behrens J, von Kries JP, Kühl M, Bruhn L, Wedlich D, Grosschedl R and Birchmeier W: Functional interaction of $\beta$-catenin with the transcription factor LEF-1. Nature 382: 638-642, 1996.

69. Huber O, Korn R, McLaughlin J, Ohsugi M, Herrmann BG and Kemler R: Nuclear localization of $\beta$-catenin by interaction with transcription factor LEF-1. Mech Dev 59: 3-10, 1996.

70. Molenaar $M$, van de Wetering $M$, Oosterwegel $M$, Peterson-Maduro J, Godsave S, Korinek V, Roose J, Destrée O and Clevers $\mathrm{H}$ : XTcf-3 transcription factor mediates $\beta$-catenin-induced axis formation in xenopus embryos. Cell 86 : 391-399, 1996.
71. Gilles C, Polette M, Mestdagt M, Nawrocki-Raby B, Ruggeri P, Birembaut $\mathrm{P}$ and Foidart JM: Transactivation of vimentin by beta-catenin in human breast cancer cells. Cancer Res 63: 2658-2664, 2003.

72. Lowy AM, Clements WM, Bishop J, Kong L, Bonney T, Sisco K, Aronow B, Fenoglio-Preiser C and Groden J: $\beta$-catenin/Wnt signaling regulates expression of the membrane type 3 matrix metalloproteinase in gastric cancer. Cancer Res 66: 4734-4741, 2006.

73. Gradl D, Kühl M and Wedlich D: The Wnt/Wg signal transducer beta-catenin controls fibronectin expression. Mol Cell Biol 19: 5576-5587, 1999.

74. Tapia JC, Torres VA, Rodriguez DA, Leyton L and Quest AF: Casein kinase 2 (CK2) increases survivin expression via enhanced beta-catenin-T cell factor/lymphoid enhancer binding factor-dependent transcription. Proc Natl Acad Sci USA 103: 15079-15084, 2006.

75. He W, Kang Y, Zhu W, Zhou B, Jiang X, Ren C and Guo W: FOXF2 acts as a crucial molecule in tumours and embryonic development. Cell Death Dis 11: 424, 2020.

76. Shao J, Cao J, Liu Y, Mei H, Zhang Y and Xu W: MicroRNA-519a promotes proliferation and inhibits apoptosis of hepatocellular carcinoma cells by targeting FOXF2. FEBS Open Bio 5: 893-899, 2015.

77. Shi Z, Liu J, Yu X, Huang J, Shen S, Zhang Y, Han R, Ge N and Yang Y: Loss of FOXF2 expression predicts poor prognosis in hepatocellular carcinoma patients. Ann Surg Oncol 23: 211-217, 2016.

78. Soutto M, Peng D, Katsha A, Chen Z, Piazuelo MB, Washington MK, Belkhiri A, Correa P and El-Rifai W: Activation of $\beta$-catenin signalling by TFF1 loss promotes cell proliferation and gastric tumorigenesis. Gut 64: 1028-1039, 2015.

79. Dang H, Takai A, Forgues M, Pomyen Y, Mou H, Xue W, Ray D, $\mathrm{Ha} \mathrm{KCH}$, Morris QD, Hughes TR and Wang XW: Oncogenic activation of the RNA binding protein NELFE and MYC signaling in hepatocellular carcinoma. Cancer Cell 32: 101-114. e8, 2017.

This work is licensed under a Creative Commons Attribution-NonCommercial-NoDerivatives 4.0 International (CC BY-NC-ND 4.0) License. 